IAWA Journal, Vol. 16 (4), 1995: 41 1-424

\title{
DENDROECOLOGICAL ANALYSIS OF CORDIA ALLIODORA, PSEUDOBOMBAX SEPTENATUM AND ANNONA SPRAGUE1 IN CENTRAL PANAMA
}

by

\author{
Margaret S. Devall', Bernard R. Parresol ${ }^{1} \&$ S. Joseph Wright $^{2}$
}

\begin{abstract}
SUMMARY
Several plant communities in central Panama, each community located near a weather station, contain trees with annual growth rings, i.e. Cordiu alliodora, Pseudobombax septenatum, and Annona spraguei. Tree-ring data are particularly valuable when concomitant weather information is readily available. Patterns of growth for the above species of trees were investigated across central Panama in relation to climate. A linear aggregate climate model was fitted to chronologies of each species at three sites along a rainfall gradient. Comparisons were made among sites to help explain how climate influences tree growth within central Panama.
\end{abstract}

Key words: Tropical dendrochronology, tropical forest, precipitation, minimum temperature, maximum temperature.

\section{INTRODUCTION}

Measuring growth rings in tropical species is difficult because annual rings are not always clearly discernible in many species, or because the equatorial climate lacks an annual season to induce dormancy and slow growth to form annual rings (e.g. Mariaux 1981; Worbes 1995)).

Crossdating is the procedure in which each ring in a tree-ring series is identified by its exact year of formation by mutually comparing a set of tree-ring series. The standardized ring-width indices from a number of trees at a site may be averaged to form a mean ring-width chronology (Fritts 1976), which can yield knowledge about the history of the plant community (Cook et al. 1987). Some tropical tree species have annual rings, but few have been crossdated (Baas \& Vetter 1989).

Devall et al. (1995) successfully crossdated tree-ring series of Cordiu alliodora, Pseudobombax septenatum and Annona spraguei from a lowland moist tropical forest in Panama. Dendrochronological studies of tropical tree species in Brazil (Worbes 1992), in India and Java (Pant 1983; Bhattacharyya et al. 1992; Jacoby \& D'Arrigo 1990) as well as in Thailand (Pumijumnong et al. 1995; Buckley et al. 1995) have already demonstrated promising results.

1) Institute for Quantitative Studies, Southern Forest Experiment Station, 701 Loyola Ave., New Orleans, LA 70113, U.S. A.

2) Smithsonian Tropical Research Institute, Unit 0948, APO AA, Miami 34002-0948, U.S.A. 
This study investigates patterns of growth of C. alliodora, $P$. septenatum, and A. spraguei across central Panama in relation to climate.

\section{MATERIAL}

Site description

In Panama, the dry season extends from December through March and part of April; November is the wettest month (Foster 1985). Along the Atlantic coast the rainfall is primarily heavy and aseasonal, with a pronounced dry season along the Pacific. Soils are mostly of fertile volcanic materials that erode rapidly with high temperatures and heavy rainstorms (D’Arcy \& Correa 1985).

Parque Metropolitan0 (Fig. 1), on the Pacific side of the Isthmus of Panama, is the driest of the three sites (Fig. 2; Balboa). It is a 265 ha park, mostly hilly with natural forests, situated in Panama City. The soils of the area are of igneous origin, clayey and brownish in colour. The forested area is composed of lowland tropical forest, heterogeneous, with a relatively continuous canopy at 30-35 metres, with occasional dominant trees to 40 metres in height. The Gamboa site (Fig. 1) is located midway along the Panama Canal (an intermediate moist climate; Fig. 2). The area is hilly, with sedimentary rock containing much volcanic debris; soils are not deep (less than $50 \mathrm{~cm}$ ) and are

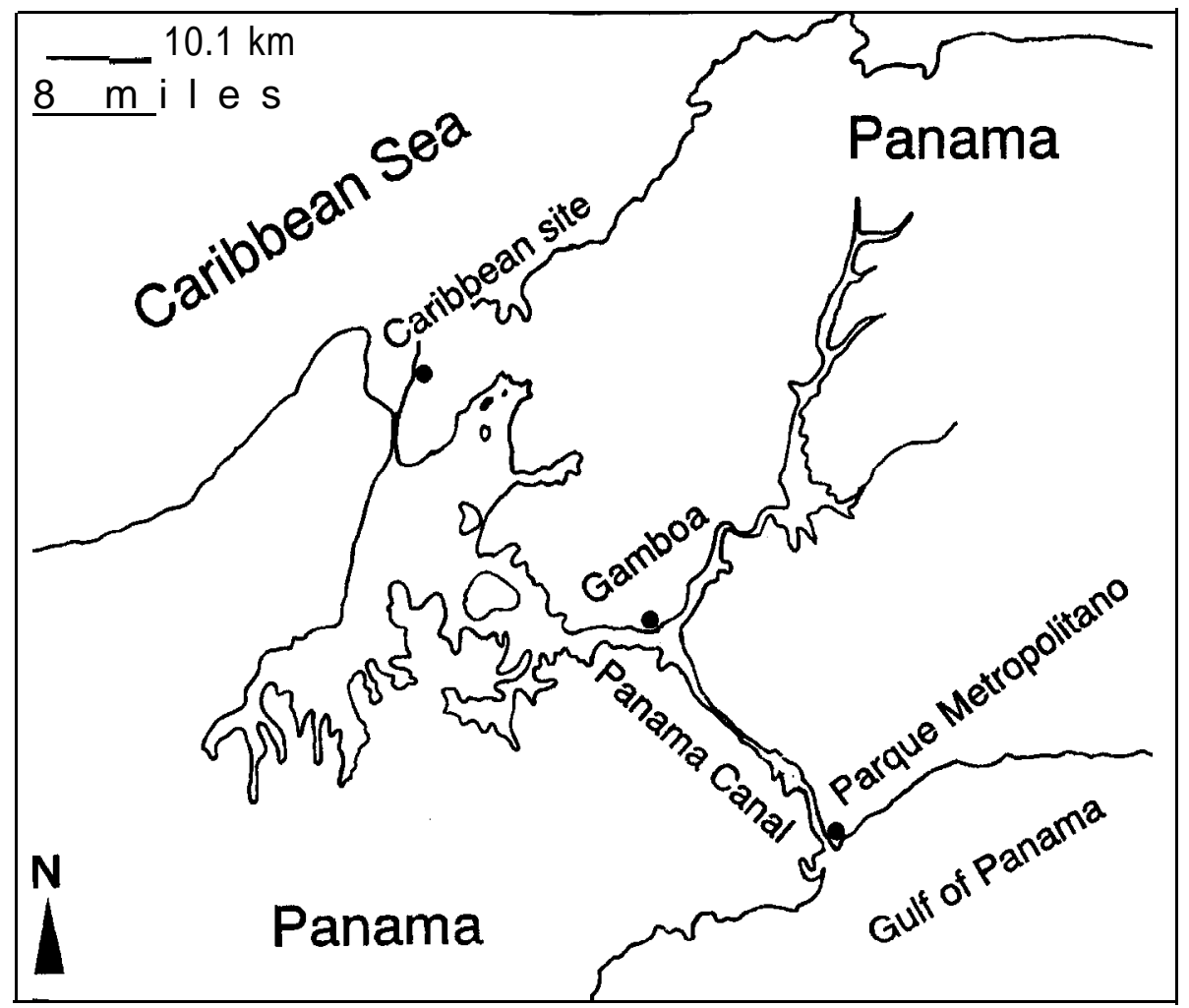

Fig. 1, Location of the three study sites across central Panama. 


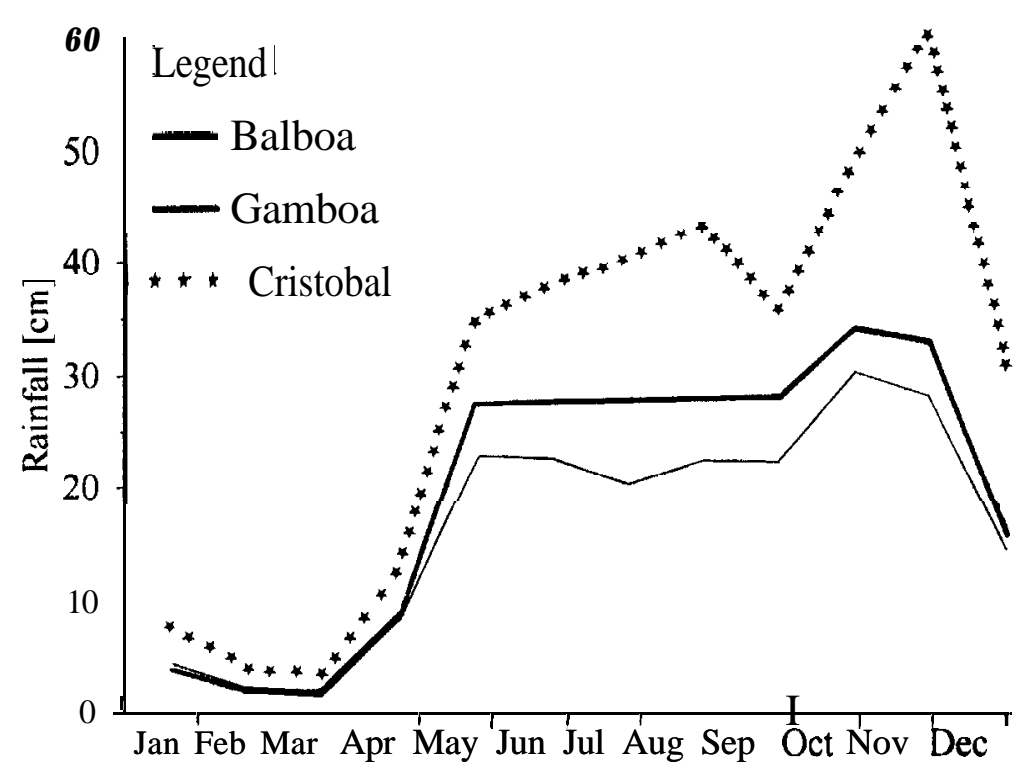

Fig. 2. Mean monthly precipitation in central Panama; data from the Meteorological and Hydrological Division of the Panama Canal Commission.

rich in clay (Dietrich et al. 1982). Tropical moist forest is dominant in this region (Foster 1985). Rainfall is mostly in storms of short duration during the rainy season, and light and sporadic during the dry season (Rand et al. 1982). The Caribbean site, Ft. Davis and Ft. Sherman (Fig. 1), is the wettest of the three sites, yet there is still a pronounced dry season (Fig. 2; Cristobal), unlike other parts of the Caribbean coast.

\section{Species}

Annona spraguei (Annonaceae) is a medium-sized tree with elliptic-oblong leaves. The species is endemic to Panama and is common about the Canal Zone (Standley 1928). Annona spraguei is facultatively deciduous at the end of the dry season. The wood is diffuse-porous.

Pseudobombax septenatum (Bombacaceae) is frequent in the Canal Zone, but is restricted to Panama and western Costa Rica. It is a large tree, often $15 \mathrm{~m}$ or more tall, with a green smooth trunk, swollen at the base. The wood is soft and is not used in construction (Standley 1928); it is diffuse-porous. Pseudobombax septenatum is deciduous during the dry season.

Cordia alliodora (Boraginaceae) is a tropical hardwood with a natural range that extends from Mexico to Argentina. The wood is diffuse-porous. It is important for timber and agroforestry. The species grows $25-30 \mathrm{~m}$ in height and $60-100 \mathrm{~cm}$ in diameter under optimum conditions (Liege1 \& Whitmore 1991). In central Panama C. alliodora is leafless during the first two months of the rainy season, then it leafs out, and there is a second flush of leaves at the end of the wet season. As the dry season progresses, the early leaves begin to drop until all the early leaves are gone. 
Table 1. Correlations of core $i$ with all other cores by species and site.

Coal

Psse $=$ Pseudobombax septenatum, Ansp = Annona spraguei.

\begin{tabular}{|c|c|c|c|c|c|c|c|c|c|}
\hline \multirow[b]{2}{*}{ Core } & \multirow{2}{*}{$\begin{array}{l}\text { Parque } \\
\text { Coal }\end{array}$} & \multicolumn{2}{|c|}{ Metropolitan0 } & \multicolumn{3}{|c|}{ Gamboa } & \multicolumn{3}{|c|}{ Caribbean } \\
\hline & & Psse & Ansp & Coal & Psse & Ansp & Coal & Psse & Ansp \\
\hline 1 & 46 & 28 & 38 & 43 & 24 & 37 & 42 & 51 & 65 \\
\hline 2 & 68 & 41 & 55 & 32 & 30 & 35 & 59 & 47 & 42 \\
\hline 3 & 44 & 35 & 18 & 55 & 48 & 19 & 39 & 42 & 48 \\
\hline 4 & 12 & 24 & 41 & 34 & 45 & 47 & 28 & 44 & 48 \\
\hline 5 & 22 & 27 & 86 & 50 & 33 & 31 & 50 & 30 & 75 \\
\hline 6 & 56 & 43 & 81 & 26 & 43 & 44 & 58 & 36 & 60 \\
\hline 7 & 64 & 35 & 83 & 63 & 40 & 73 & 39 & 31 & 56 \\
\hline 8 & 67 & 37 & 33 & 31 & 48 & 63 & 34 & 49 & 43 \\
\hline 9 & 74 & 34 & 61 & 62 & 31 & 41 & 41 & 37 & 51 \\
\hline I 0 & 26 & 25 & 61 & 31 & 43 & 36 & 47 & 52 & 61 \\
\hline 11 & 35 & 58 & 50 & 64 & 47 & 61 & 39 & 45 & 48 \\
\hline 12 & 57 & 43 & 44 & 54 & 27 & 64 & 62 & 61 & 40 \\
\hline 13 & 46 & 38 & 35 & 52 & 17 & 60 & 47 & 38 & 47 \\
\hline 14 & 23 & 38 & 34 & 5 & 45 & 34 & 45 & 56 & 37 \\
\hline 15 & 57 & 33 & 65 & 47 & 37 & 59 & 42 & 28 & 53 \\
\hline 16 & 45 & 30 & 14 & 37 & 42 & 30 & 28 & 34 & 72 \\
\hline 17 & 38 & 49 & 27 & 73 & 49 & 19 & 45 & 63 & 56 \\
\hline 18 & 31 & 33 & 30 & 67 & 31 & 64 & 51 & 41 & 54 \\
\hline 19 & 52 & 90 & 30 & 30 & 60 & 61 & 48 & 41 & 71 \\
\hline 20 & 63 & 54 & 74 & 59 & 33 & 75 & 33 & 45 & 78 \\
\hline 21 & 45 & 11 & 80 & 15 & 70 & 49 & 40 & 35 & 89 \\
\hline 22 & 65 & 22 & 69 & 21 & 71 & 30 & 37 & 27 & 59 \\
\hline 23 & 61 & 18 & 71 & 54 & 42 & 38 & 39 & 22 & 50 \\
\hline 24 & 32 & 37 & 40 & 28 & 30 & 57 & 36 & 29 & 76 \\
\hline 25 & 60 & 27 & 44 & 56 & 46 & 59 & 43 & 37 & 47 \\
\hline 26 & 56 & 37 & 60 & 49 & 66 & 44 & 36 & 29 & 24 \\
\hline 27 & 67 & 33 & 42 & 28 & 37 & 43 & 48 & 26 & 58 \\
\hline 28 & 69 & 24 & 58 & 39 & 41 & 55 & 54 & 63 & 41 \\
\hline 29 & 59 & 32 & 63 & 37 & 44 & 38 & 60 & 45 & 55 \\
\hline 30 & 70 & 22 & 50 & 37 & 18 & 49 & 28 & 43 & 39 \\
\hline 31 & 41 & 32 & 56 & 52 & 30 & 43 & 48 & 49 & 46 \\
\hline 32 & 30 & & 35 & 50 & 43 & 29 & 86 & 38 & 58 \\
\hline 33 & 19 & & 55 & 32 & 34 & 11 & 30 & 34 & 47 \\
\hline 34 & 40 & & 21 & 44 & 29 & 35 & 40 & 58 & 63 \\
\hline 35 & & & 71 & 52 & & 27 & 38 & 41 & 67 \\
\hline 36 & & & 53 & 32 & & 72 & 70 & 42 & 38 \\
\hline 37 & & & 69 & 35 & & 77 & 40 & 57 & 50 \\
\hline 38 & & & 26 & 48 & & 41 & 50 & 49 & 51 \\
\hline 39 & & & 22 & 41 & & 32 & 71 & 42 & \\
\hline 40 & & & 64 & 31 & & 27 & 56 & 21 & \\
\hline 41 & & & 39 & 50 & & 44 & 33 & & \\
\hline 42 & & & 52 & 36 & & 16 & 41 & & \\
\hline 43 & & & 67 & 65 & & 55 & 57 & & \\
\hline 44 & & & 51 & 60 & & 44 & 39 & & \\
\hline 45 & & & 34 & 48 & & & 50 & & \\
\hline 46 & & & 38 & 24 & & & 61 & & \\
\hline 47 & & & 48 & & & & 45 & & \\
\hline 48 & & & 59 & & & & & & \\
\hline 49 & & & 41 & & & & & & \\
\hline 50 & & & 47 & & & & & & \\
\hline 51 & & & 29 & & & & & & \\
\hline 52 & & & 33 & & & & & & \\
\hline 53 & & & 36 & & & & & & \\
\hline 54 & & & 58 & & & & & & \\
\hline
\end{tabular}




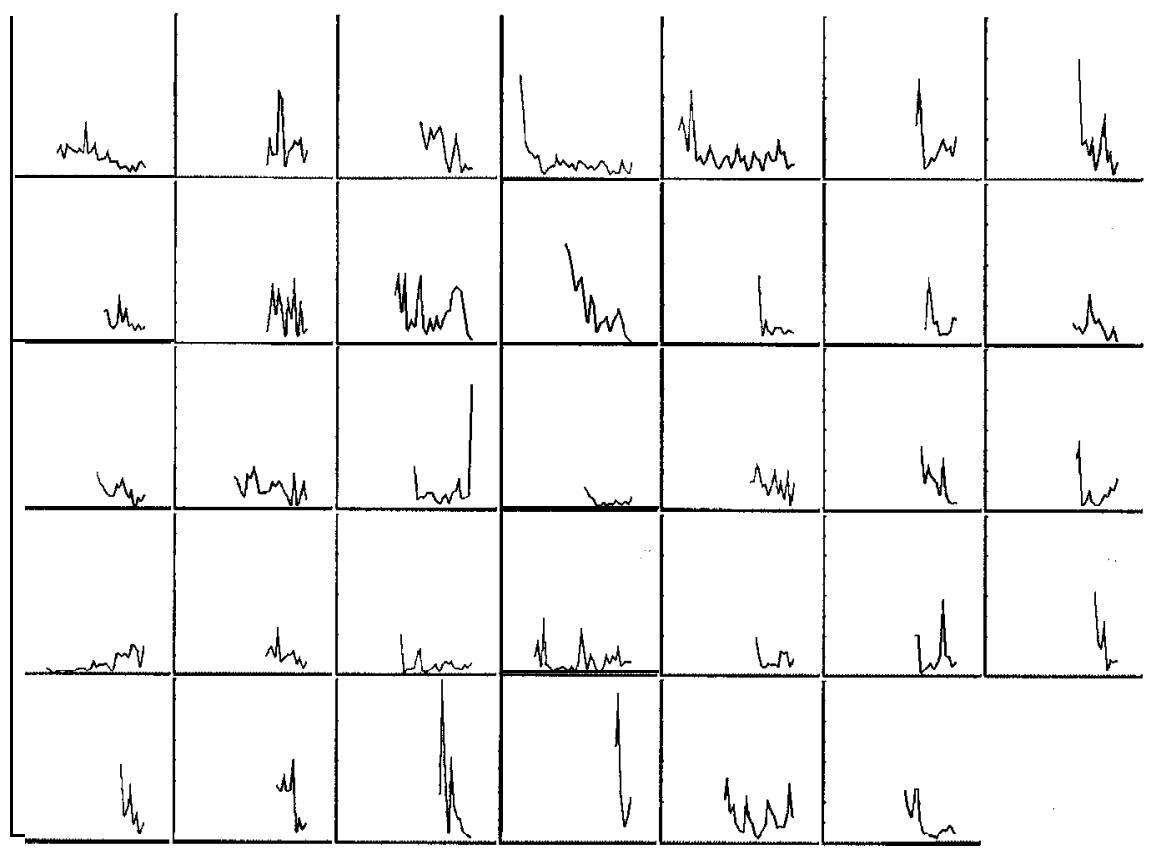

Fig. 3. Full ring-width series for Cordia alliodora at Parque Metropolitano.

\section{METHODS}

We sampled approximately 31 trees of each species at each of the three study sites during April 1993. We collected two cores per tree. The cores were air dried, mounted on wooden blocks, and hand sanded with three grades of sandpaper. Cores were then scrutinized for defects and the best ones selected for the analysis; cores with indistinct rings, rotten spots, or fungus growth were eliminated. We measured ring widths and crossdated the tree-ring series (Fig. 3; Table 1) using software developed by Van Deusen (1987, 1993). Identification of marker rings helped establish correct crossdating, but use of the software was the primary method of crossdating.

After crossdating, we developed a mean chronology for each species per location. In order to optimize the climate component of the ring widths and the disturbance signal common to most of the trees (see Graybill1982), we standardized the cores by using the first difference of the inverse hypersine (Van Deusen 1987, 1990). This removed the biological growth trend and achieved homogeneous variances.

We obtained total monthly rainfall plus average maximum, minimum, and mean monthly temperatures from the Meteorological and Hydrological Division of the Panama Canal Commission for the three sites. Data were collected at all sites since 1911 or earlier, except temperature data at Gamboa (195 1). We used the ALLREGS program, one of the DYNACLIM system of programs (Van Deusen 1993), to screen all possible climate models to determine which factors had the most effect on growth for each of the 
Table 2. Correlations between species growth chronologies and climate variables at three sites along a rainfall gradient in central Panama.

$$
\mathrm{P}=\text { Parque Metropolitano, } \mathrm{G}=\text { Gamboa, } \mathrm{C}=\text { Caribbean site; }
$$

cor $=$ correlation, est $=$ estimate, prob $=$ probability $-\mathrm{mx} \mathrm{t}=$ maximum temperature, $\mathrm{mn} \mathrm{t}=$ minimum temperature.

\begin{tabular}{|c|c|c|c|c|c|c|c|c|c|c|c|c|c|c|c|c|c|c|}
\hline & \multicolumn{6}{|c|}{ Annona spraguei } & \multicolumn{6}{|c|}{ Cordia alliodora } & \multicolumn{6}{|c|}{ Pseudobombax septenatum } \\
\hline & \multicolumn{3}{|c|}{ Variable + cor } & \multirow{2}{*}{\multicolumn{2}{|c|}{$\begin{array}{cc} & \text { est } \\
0 & -0.02\end{array}$}} & \multirow{2}{*}{$\frac{\text { prob }}{0.04}$} & \multicolumn{3}{|c|}{ Variable + cor } & \multirow{2}{*}{\multicolumn{2}{|c|}{$\begin{array}{c}\text { est } \\
0.04\end{array}$}} & \multirow{2}{*}{$\begin{array}{c}\text { prob } \\
<0.00\end{array}$} & \multicolumn{3}{|c|}{ Variable + cor } & \multirow{2}{*}{\multicolumn{2}{|c|}{$\begin{array}{c}\text { est } \\
0.03\end{array}$}} & \multirow{2}{*}{$\begin{array}{c}\text { prob } \\
0.01\end{array}$} \\
\hline $\mathrm{P}$ & -0.46 & Oct & ram lag & & & & +0.39 & Oct & ram lag & & & & +0.25 & Oct & rain lag & & & \\
\hline & -0.51 & Nov & ram lag & 0 & -0.02 & 0.05 & -0.04 & Jul & $\mathrm{mxt}$ lag & 1 & -0.19 & $<0.00$ & +0.23 & Jul & rain lag & 1 & 0.03 & 0.02 \\
\hline & +0.39 & Oct & ram lag & 1 & 0.03 & 0.01 & -0.01 & Aug & mx t lag & 1 & 0.19 & $<0.00$ & -0.27 & Oct & rain lag & 1 & -0.03 & 0.01 \\
\hline \multirow[t]{3}{*}{ G } & +0.43 & Sep & rain lag & 0 & 0.04 & 0.01 & -0.16 & $\mathrm{Feb}$ & mx t lag & 1 & -0.27 & 0.01 & -0.43 & May & ram lag & 0 & -0.05 & $<0.00$ \\
\hline & -0.32 & Aug & rain lag & 1 & -0.03 & 0.04 & +0.09 & Mar & $\mathrm{mxtlag}$ & 1 & 0.21 & 0.01 & -0.17 & Feb & rain lag & 1 & -0.08 & 0.30 \\
\hline & +0.33 & Dec & rain lag & 1 & 0.04 & 0.02 & +0.31 & Feb & $\mathrm{mxt}$ lag & 2 & 0.11 & 0.04 & +0.24 & Jul & rain lag & 1 & 0.03 & 0.05 \\
\hline \multirow[t]{3}{*}{$\mathrm{C}$} & -0.19 & Apr & mn t lag & 0 & -0.22 & 0.00 & -0.50 & Jul & rain lag & 0 & -0.04 & $<0.00$ & +0.32 & Oct & mntlag & 0 & 0.12 & $<0.00$ \\
\hline & +0.41 & Oct & mn t lag & 0 & 0.11 & 0.01 & +0.17 & Apr & $\mathrm{mn}$ tlag & 1 & 0.14 & 0.02 & -0.21 & Nov & mn t lag & 1 & -0.08 & $<0.00$ \\
\hline & +0.81 & Sep & $\mathrm{mnt}$ lag & 1 & 0.28 & 0.00 & -0.27 & Nov & $\mathrm{mn} \mathrm{t}$ lag & 1 & -0.14 & $<0.00$ & 0.06 & Oct & $\mathrm{mn} \mathrm{t}$ lag & 2 & 0.05 & 0.12 \\
\hline
\end{tabular}


three species per site. The program ALLREGS computes all possible least-squares regressions of the dependent variable, the standardized chronology, against all of the independent variables (climate). We analysed the 12 monthly precipitation and temperature variables and one and two year lags of these variables. We also studied the climate data to find any extreme values. We used the program DYNAOLS to study the climate models that we found by doing all possible regressions with ALLREGS. We fitted climate models to the nine chronologies. The program DYNAOLS allows one to perform ordinary least squares and to look at regression diagnostics. With short-term chronologies $(<100$ years) long-term trends and slowly changing patterns cannot be investigated. Thus the linear aggregate model (as fit by DYNAOLS) does as well with short chronologies as more sophisticated models, such as the random coefficient model (as fit by DYNACLIM).

\section{RESULTS}

Annona spraguei - The oldest core from Parque Metropolitan0 dated back to 1960, but 1961 was the first year in which more than one tree was present. Our analysis used first differenced inverse hypersine data; taking the first difference of the ring widths eliminated the first observation, so 1962 was the starting year. Current October and November rainfall, and October rainfall lagged one year (Table 2), were the best predictors of growth for the A. spraguei chronology at Parque $\left(\mathrm{R}^{2}=0.49, \mathrm{p}=0.001\right)$. Current September rain and August and December rain lagged one year had the largest effect on growth at Gamboa $\left(\mathrm{R}^{2}=0.44, \mathrm{p}=0.003\right)$. However, the best estimators of growth at Ft. Sherman (Caribbean site) were April and October minimum temperature and September minimum temperature lagged one year $\left(\mathrm{R}^{2}=0.89, \mathrm{p}<0.001\right)$.

The observed and expected values of the standardized ring widths of A. spraguei over time are shown in Figure 4. Predicted growth was obtained from the program DYNAOLS with the climate variables mentioned above. The observed and predicted values are similar, and run in the same direction most of the time.

Cordia alliodora - The trees averaged about 10 years older than those of Annona spraguei. The best predictors of growth of C. alliodora at Parque were July and August maximum temperature of the previous year and October precipitation $\left(\mathrm{R}^{2}=\right.$ $0.38, \mathrm{p}=0.002$ ). The top estimators of growth at Gamboa were February and March maximum temperature lagged one year and February maximum temperature lagged two years $\left(\mathrm{R}^{2}=0.33, \mathrm{p}=0.02\right)$. July precipitation, and April and November minimum temperature lagged one year predicted growth of $\mathbf{C}$. alliodora best at Ft. Davis (Caribbean site) $\left(R^{2}=0.49, p<0.001\right)$. The observed and expected values of the ring widths of $\mathbf{C}$. alliodora are shown in Figure 5.

Pseudobombax septenatum - October precipitation of the current and the past year and June precipitation of the past year were the best predictors of the chronology at Parque $\left(\mathrm{R}^{2}=0.20, \mathrm{p}=0.001\right)$. The best predictors of growth of the species at Gamboa were May rainfall, and February and July rainfall lagged one year $\left(\mathrm{R}^{2}=0.28, \mathrm{p}=\right.$ 0.006). At the Caribbean site, October minimum temperature of the current year and 

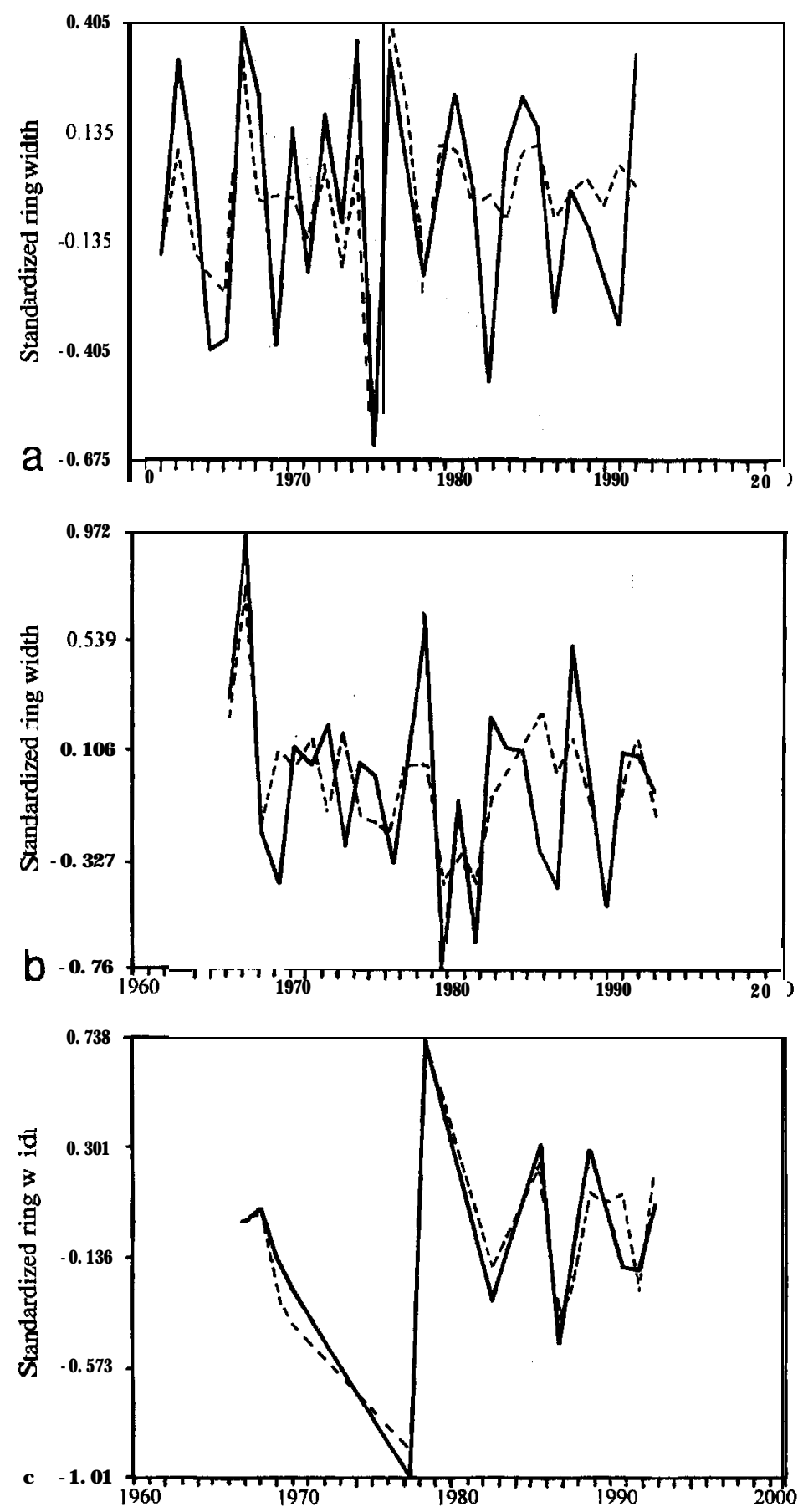

Fig. 4. Annona spraguei, the observed (solid) vs predicted (dashed) values calculated with the climate variables of the months listed in Table 2. -a: Metropolitano, b: Gamboa, c: Ft. Sherman. 

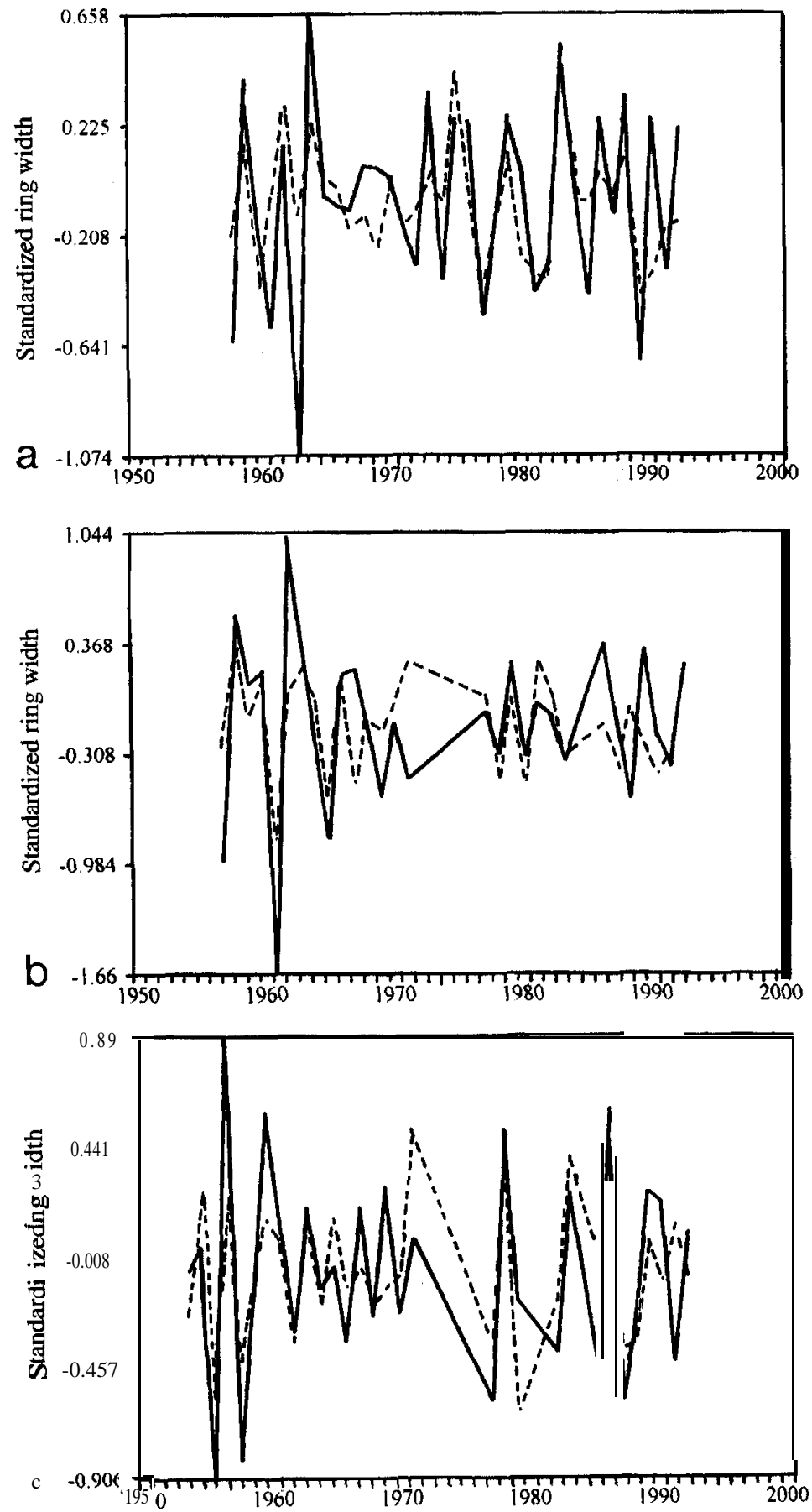

Fig. the observed (solid) vs predicted (dashed) values with the climate variables of the months listed in Table 2. - a: Metropolitano, b: Gamboa, c: Ft. Sherman. 

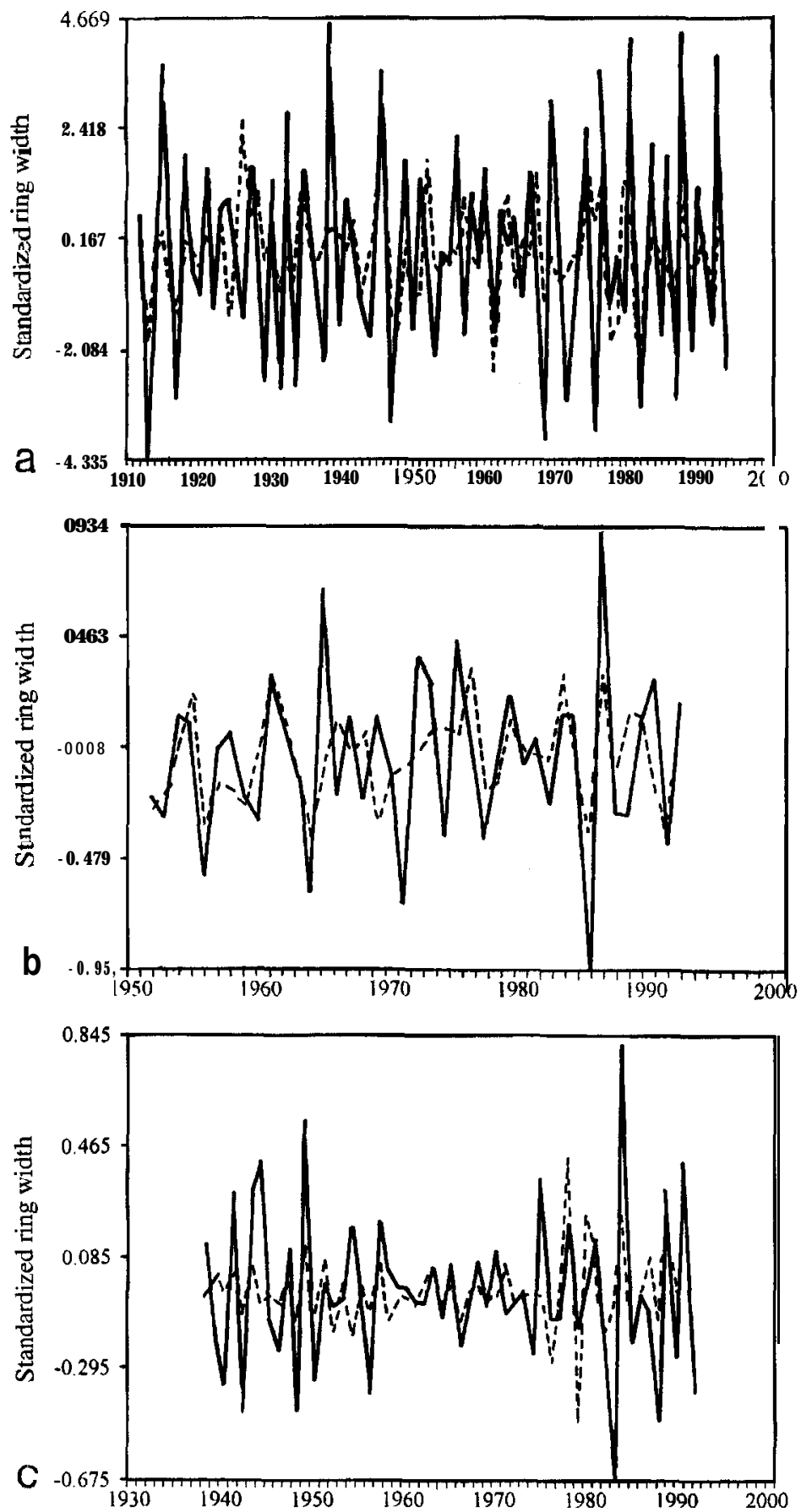

Fig. 6. Pseudobombax septenatum, observed (solid) vs predicted (dashed) values calculated with climate variables of the months listed in Table 2. -a: Metropolitano, b: Gamboa, c: Ft. Sherman. 
of two years past as well as November minimum temperature lagged one year were the most influential months on the growth of P. septenatum $\left(\mathrm{R}^{2}=0.25, \mathrm{p}=0.002\right)$. The observed and expected values of the ring widths of $P$, septenatum are shown in Figure 6.

\section{DISCUSSION}

The expected values of the tree-ring data of all species at the three sites predicted growth, confirming that the rings are truly annual. This is in accord with Augspurger (1985), who concluded that in the tropics the most obvious environmental stimuli with the sharpest, most rapid change in environmental conditions seem to be either rainfall sufficient to end a drought and the concomitant change in soil moisture, or changes in temperature attending a tropical storm.

The principle of limiting factors is important to dendrochronology (Fritts 1976). Rainfall had the most influence on growth of A. spraguei and P. septenatum at the Parque and at Gamboa, but at the Caribbean site minimum temperature was more important to all three species. Although there appears to be plenty of rain at all three sites, the soil is porous, and rainfall can be a limiting factor, especially during the dry season. Barro Colorado Island, near our Gamboa site, received less than $100 \mathrm{~mm}$ of rain during the first three months of the year in more than half the years of record although total annual rainfall was over $2500 \mathrm{~mm}$. The dry season in that area affects every feature of the community (Leigh 1982), and apparently causes ring widths to vary the same way in a number of trees (Fritts 1976). At the Caribbean site, there is more total rainfall and more rain during the dry season, so minimum temperature becomes the limiting factor instead of precipitation.

October rain was important to growth of the three species at Parque, and October minimum temperature predicted growth best for $A$. sprague $i$ and I? septenatum at the Caribbean site. Perhaps October temperature and rainfall influence tree growth because of the 'veranillo'; this is a short dry season, which often occurs between August and October. There are many cloudy days in central Panama during the rainy season, but when the 'veranillo' comes there are more clear sunny days, so more photosynthesis results, resulting in increased growth of the trees.

At the Caribbean site, mean minimum temperature in various months from up to two prior years is influential for all three species, sometimes positively, sometimes negatively.

Growth of $C$. alliodora at Parque, at Gamboa and at Barro Colorado Island (Devall et al. 1995) was weakly correlated with maximum temperature, unlike that of $A$. spraguei and P. septenatum. The phenology of C. alliodora is different from that of most plant species in Panama [loses leaves after the rainy season begins (Foster 1985)], so it is not surprising that growth in this species is influenced by different climate variables.

At Gamboa, rain or maximum temperature between December and May are important for all three species. When rain is positively correlated with ring width, drought appears to be limiting growth. When maximum temperature is negatively correlated with growth, the mechanism may also be drought, since rain mitigates high dry season temperatures, 
At Parque, October and November rain are important for all three species. October rain is positively correlated with growth for C. alliodora and $P$. septenatum, but negatively correlated with growth of $A$. spraguei. Perhaps $A$. sprague $i$ is less able than the other two species to grow well with loss of soil structure and aeration due to saturation for prolonged periods.

Conditions of the current and previous two years influenced the growth of the trees. Development of buds, accumulation of photosynthates, formation of growth hormones and other growth processes occur long before actual radial growth develops, hence previous variations in climate can influence the ring width of the current year (D' Arrigo \& Jacoby 1992). Also, a factor may have a positive influence on growth during one year and a negative influence the year before, for example October rain had a negative influence on growth of $A$. spraguei at Parque, but October rainfall of the previous year had a positive influence. Fritts and Swetnam (1986) state that a variety of components usually influence the complex process involved in diameter growth of trees, and each factor may function in a variety of ways. Limiting processes can change considerably during the year (Fritts 1976).

\section{CONCLUSION}

Along the rainfall gradient, the precipitation variables we studied had the strongest influence on growth of $A$. spraguei and P. septenatum at Parque and Gamboa. They cease to be limiting factors at the Caribbean site, where mean minimum temperature is very influential. Conditions around the month of October are especially influential to all three species, suggesting that the 'veranillo' affects growth of the trees. Mean maximum temperature is associated with the growth response of C. alliodora, a species with an unusual phenology (leafless during the rainy season). However, minimum temperature is most influential at the Caribbean site. Trees no doubt were also responding to factors not considered in this study, such as solar radiation or humidity.

\section{ACKNOWLEDGEMENTS}

This research was supported by the Smithsonian Institution (including short-term visitor grants to Devall and Parresol) and the U. S.D.A. Forest Service. We thank Leonard Thien and Charles Thomas for reviewing the manuscript.

\section{REFERENCES}

Augspurger, C.K. 1985. Flowering synchrony of neotropical plants. In: W.D. D’Arcy \& M.D. Correa A. (eds.), The botany and natural history of Panama: 255-262. Missouri Botanical Garden, St. Louis.

Baas, P. \& R.E. Vetter (eds.). 1989. Growth rings in tropical woods. IAWA Bull. n. s. 10: 95174.

Bhattacharyya, A., R.R. Yadav, H.P. Borgaonkar \& G.B. Pant. 1992. Growth-ring analysis of Indian tropical trees: dendroclimatic potential. Current Science 62: 736-741.

Buckley, B.M., M. Barbetti, M. Watanasak, R.D. D'Arrigo, S. Boonchirdchoo \& S. Sarutanon. 1995. Dendrochronological investigations in Thailand. IAWA J. 16: 393-409 (this issue). 
Cook, E.R., A.H. Johnson \& T. J. Blasing. 1987. Forest decline: modeling the effect of climate in tree rings. Tree Physiology 3: 27-40.

D’Arcy, W.G. \& M.D. Correa. 1985. Panama information. In: W.D. D' Arcy \& M.D. Correa A. (eds.), The botany and natural history of Panama: xix-xxi. Missouri Botanical Garden, St. Louis.

D’Arrigo, R.D. \& G.C. Jacoby. 1992. A tree-ring reconstruction of New Mexico winter precipitation and its relation to El Niño/Southern Oscillation events. In: H.F. Diaz \& B. Markgraf (eds.), El Niño: historical and paleoclimatic aspects of the Southern Oscillation: 7-28. Cambridge Univ. Press, New York.

Devall, M.S., B.R. Parresol \& K. Lê. 1995. Dendroecological analysis of laurel (Cordia alliodora) and other species from a lowland moist tropical forest in Panama. In: J.S. Dean, D.M. Meko \& T.W. Swetnam (eds.), Proc. International Conference on Tree Rings, Environment, and Humanity; 1994, May 17-21; Tucson, AZ. In press.

Dietrich, W.E., D.M. Windsor \& T. Dunne. 1982. Geology, climate and hydrology of Barro Colorado Island. In: E.G. Leigh Jr., A.S. Rand \& D. Windsor (eds.), The ecology of a neotropical forest: seasonal rhythms and long-term changes: 21-46. Smithsonian Inst. Press, Washington, D.C.

Foster, R.B. 1985. Plant seasonality in the forests of Panama. In: W. D. D' Arcy \& M.D. Correa

A. (eds.), The botany and natural history of Panama: 255-262. Missouri Botanical Garden, St. Louis.

Fritts, H.C. 1976. Tree rings and climate. Acad. Press, London.

Fritts, H.C. \& T.W. Swetnam. 1986. Dendroecology: a tool for evaluating variations in past and present forest environments. Univ. of Arizona, Tucson.

Graybill, D.A. 1982. Chronology development and analysis. In: M.K. Hughes, PM. Kelly, J.R. Pilcher \& V.C. LaMarche (eds.), Climate from tree rings: 21-28. Cambridge Univ. Press, Cambridge.

Jacoby, G. C. \& R.D. D' Arrigo. 1990. Teak (Tectona grandis L. f.), a tropical species of largescale dendroclimatic potential. Dendrochronologia 8: 83-98.

Leigh, E.G. Jr. 1982. Introduction. In: E.G. Leigh Jr., A.S. Rand \& D.M. Windsor (eds.), The ecology of a neotropical forest: seasonal rhythms and long-term changes: 11-17. Smithsonian Insti. Press, Washington, D.C.

Liegel, L.H. \& J.L. Whitmore. 1991. Cordia alliodora. In: R.M. Burns \& M. Mosquera (eds.), Useful trees of tropical North America. North American Forestry Commission Publication 3. U.S. Dept of Agriculture, Washington, D.C. (In English/Spanish.)

Mariaux, A. 1981. Past efforts in measuring age and annual growth in tropical trees. In: F.H. Bormann \& G. Berlyn (eds.), Age and growth rate of tropical trees: New directions for research: 20-30. Yale Univ., School of Forestry and Environm. Studies, Bull. 94.

Pant, G. B. 1983. Climatological signals from the annual growth-rings of selected tree species of India. Mausam 34: 251-256.

Pumijumnong, N., D. Eckstein \& U. Sass. 1995. Tree-ring research on Tectona grandis in northern Thailand. IAWA J. 16: 385-392 (this issue).

Rand, A. S. \& W. R. Rand. 1982. Variation in rainfall on Barro Colorado Island. In: E.G. Leigh Jr., A. S. Rand \& D.M. Windsor (eds.), The ecology of a neotropical forest: seasonal rhythms and long-term changes: 1 1-17. Smithsonian Inst. Press, Washington, D.C.

Standley, P.C. 1928. Flora of the Panama Canal Zone. Contributions from the United States National Herbarium, Vol. 27. U.S. Govt Printing Office, Washington, D.C.

Van Deusen, P.C. 1987. Testing for stand dynamics effects on red spruce growth trends. Can. J.

For. Res. 17: 1487-1495. 
Van Deusen, P.C. 1990. A dynamic program for cross-dating tree rings. Can. J. For. Res. 20: 200-205.

Van Deusen, P.C. 1993. Dynaclim Version 3.2 User's Manual: 1-28. USDA Forest Service, Southern Forest Experiment Station, Institute for Quantitative Studies, New Orleans.

Worbes, M. 1992. Occurrence of seasonal climate and tree-ring research in the tropics. Lundqua Report No. 34: 338-342.

Worbes, M. 1995. How to measure growth dynamics in tropical trees - A review. IAWA J. 16: 337-351 (this issue). 